\title{
Biodegradable polymer materials and modifying additives: state of the art. Part I
}

\author{
I.N. Vikhareva* iD, I.I. Zaripov (D), D.F. Kinzyabulatova (D, N.S. Minigazimov, G.K. Aminova \\ Ufa State Petroleum Technological University, Ufa, Bashkortostan Republic, Russia \\ * Contacts: e-mail: irina.vikhareva2009@yandex.ru
}

\begin{abstract}
One of the most demanded materials on the planet is plastic, the excellent performance of which contributes to the accumulation of a significant amount of waste on its basis. In this regard, a new approach to the development of these materials has been formed in scientific circles: the production of polymer composites with constant performance characteristics for a certain period and then capable of destruction under the influence of environmental factors. Analysis of the current state of the industry of polymeric materials shows that the most urgent is the use of such classical polymers as polyolefins and polyvinyl chloride. First of all, the optimal solution to this problem due to the lack of a suitable replacement for traditional polymers is the development of composites based on them with the use of biodegradable additives. In this case, a set of problems associated with waste disposal is solved: the decomposition period of the recycled waste is significantly reduced, the territories required for plastic waste are reduced. The paper outlines the preconditions for the emergence and further development of the field of biodegradable polymers. The main quantitative characteristics of the production capacities of manufactured bioplastics by types, regions and industries of application are given.

Modern methods of reducing and regulating the degradation time of polymer materials are presented. The main global and domestic manufacturers of biodegradable polymers and their products are listed, as well as a list of the main manufacturers of biodegradable additives for polymeric materials. Modern types of bioplastics based on renewable raw materials, composites with their use, as well as modified materials from natural and synthetic polymers are listed. The main methods for determining the biodegradability of existing bioplastics are described.
\end{abstract}

KEYWORDS: biodegradation, biodegradable additives, petrochemical raw materials, polymers, plasticizers, plant sources.

FOR CITATION: Vikhareva I.N., Zaripov I.I., Kinzyabulatova D.F., Minigazimov N.S., Aminova G.K. Biodegradable polymer materials and modifying additives: state of the art. Part I. Nanotechnologies in Construction. 2020; 12(6): 320-325. Available from: doi: 10.15828/2075-8545-2020-12-6-320-325.

\section{INTRODUCTION}

$\mathrm{T}$ he global environmental problem of our time is the accumulation of wastes of polymer materials in the biosphere. Worldwide, nearly 380 million tons of plastics are produced annually [1]. About $9 \%$ is recycled, about $12 \%$ of polymer waste is incinerated [2-4]. The remaining $79 \%$ end up in landfills that occupy huge areas and remove millions of hectares of fertile land from agricultural circulation.

The problem is compounded by the fact that, due to improper burial, almost 12 million tons of plastic are carried annually by rivers into the seas and oceans [5]. As a result, the Pacific Ocean formed the Great Pacific
Garbage patch, the area of which, according to experts, is about 1.5 million square kilometers.

There are two main areas of solution: disposal of plastic waste and creation of biodegradable plastics [6-8].

The main ways to reduce the volume of synthetic plastic waste are incineration and recycling [9-11]. However, burning does not fundamentally improve the environmental situation. Moreover, the combustion of polymeric materials is an expensive process accompanied by the release of highly toxic contaminants (dioxins, furans, etc.) [12-15]. The processing of polymer wastes results in a higher cost of the material, while the quality of the obtained polymer decreases [13-18].

The development of new technologies aimed at the production of environmentally sound materials and

(c) Vikhareva I.N., Zaripov I.I., Kinzyabulatova D.F., Minigazimov N.S., Aminova G.K., 2020 


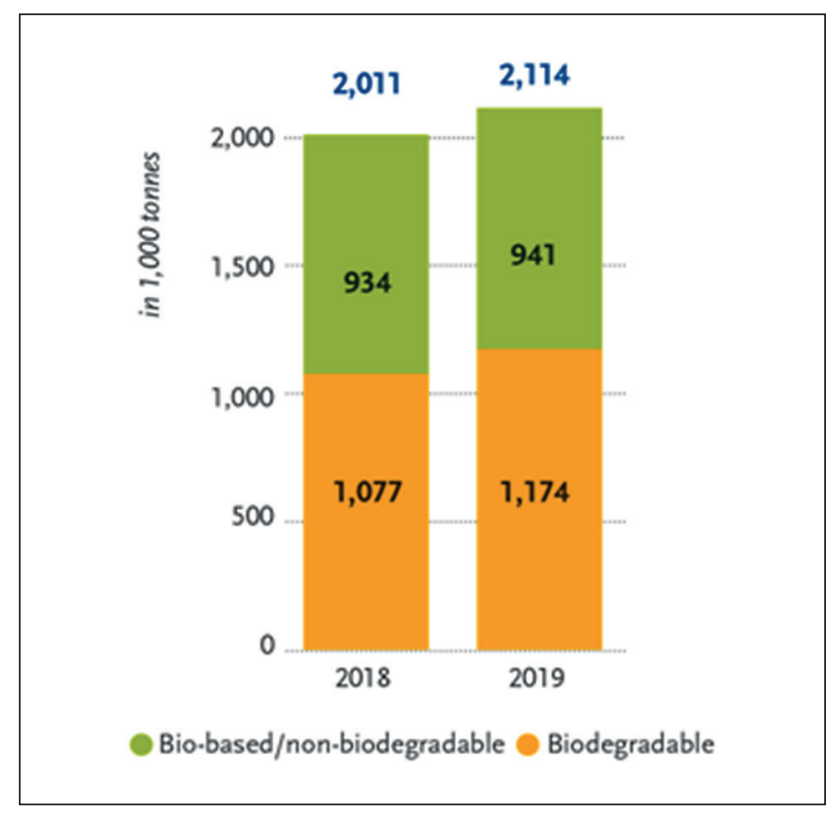

Fig. 1. Production capacity of bioplastics in 2018-2019, thousand tons

\section{Source: European Bioplastics Institute}

excluding emissions of pollutants, as well as integrated waste treatment, are consistent with the concept of environmentally sound sustainable development of human activities adopted by the UN at the Conference on Environment and Development back in 1992 [19-20].

Giving traditional polymers the ability to biodegrade under the influence of microorganisms and natural-climatic factors will significantly reduce the volume of poly- mer waste and, thereby, improve the environmental situation.

The optimal solution is the development of self-destructing polymer materials, especially for products with a short life cycle (packaging materials, disposable utensils, pens, razors, transport pallets), which must maintain technological characteristics during storage and operation, after which, under the action of certain factors (microorganisms, light, oxygen air, water), must decompose in a short period of time.

Existing biodegradable bio-based polymers are more expensive than synthetic polymers [21-22]. Therefore, biodegradable polymeric materials are mainly obtained by mixing thermoplastic synthetic polymers and biodegradable fillers of natural origin.

Currently, the production and consumption of bioplastics is only about $1 \%$ of the total amount of PM [23]. As demand and applications grow and new more complex biopolymers emerge, the bioplastics market grows and diversifies.

According to the latest data from the European Bioplastics Institute (European Bioplastics) and the novaInstitute Research Institute (Hürth, Germany), the global production capacity for the production of bioplastics in 2019 amounted to 2,114 million tons (Fig. 1) [23].

The main applications in the bioplastics consumption market are constantly changing. However, packaging remains the largest field of application of bioplastics, in 2019 it accounted for more than 53\% (1.14 million tons) of the entire bioplastics market [23]. Segments, such as automotive/transport and construction, significantly increased their share in 2019 (Fig. 2).

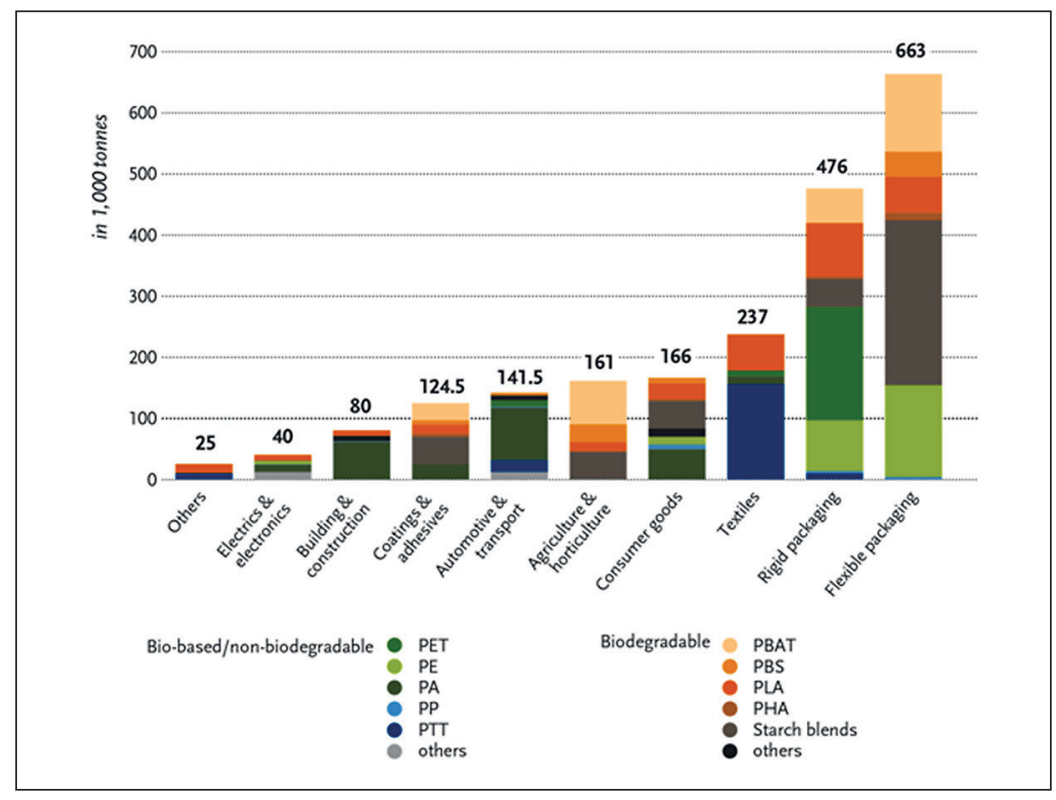

Fig. 2. Production capacity of bioplastics by application industry in 2019, thousand tons Source: European Bioplastics Institute 
Nanotechnologies in construction Нанотехнологии в строительстве

\section{DEVELOPMENT OF NEW POLYMER MATERIALS}

\section{Table 1}

\section{Major producers of biodegradable PM}

\begin{tabular}{|c|c|c|}
\hline № & Producer & Product Name and Application \\
\hline 1 & $\begin{array}{l}\text { Archer Daniel Mildland Co. } \\
\text { (USA) }\end{array}$ & Polylactides, polyhydroxybutyrates \\
\hline 2 & BASF AG (Germany) & $\begin{array}{l}\text { Polyesters of Butane-1,4-diol, terephthalic and adipic acids Ecoflex, Eastar Bio, additives for } \\
\text { the production of biodegradable plastics }\end{array}$ \\
\hline 3 & BAYER AG (Germany) & $\begin{array}{l}\text { Polyester amides BAK - thermoplastic polymer, like conventional thermoplastics for injection } \\
\text { molding, extrusion, fiber production }\end{array}$ \\
\hline 4 & Biotec Gmb H. (Germany) & Starch filled plastics “Bioplast” for compost bags, dishes, forks, spoons, cups \\
\hline 5 & Cargill Inc. (USA) & Polylactides Eco-PLA for injection molding, thermoforming, production of nonwoven fabric \\
\hline 6 & Chronopol (USA) & Synthesis of polylactic acid \\
\hline 7 & $\begin{array}{l}\text { CSM N.V. / Cargill Inc. } \\
\text { (Holland) }\end{array}$ & Polylactides \\
\hline 8 & $\begin{array}{l}\text { DAICEL Chem. Ind. Ltd } \\
\text { (Japan) }\end{array}$ & Composites based on polylactide, cellulose acetate \\
\hline 9 & Du Pont Co. (USA) & Polylactides from milk, cheese and corn ECO Chem., Copolymer with polyester - Biomax \\
\hline 10 & Ecolean (Sweden) & Packaging and equipment for filling liquid food products into branded "jugs" \\
\hline 13 & $\begin{array}{l}\text { EPI Environmental } \\
\text { Technologies Inc. } \\
\end{array}$ & Raw materials for the production of oxo-biodegradable packaging \\
\hline 14 & $\begin{array}{l}\text { GREENSAN LIMITED Srls } \\
\text { (Italy) }\end{array}$ & Compostable packaging for food and industrial products \\
\hline 15 & $\begin{array}{l}\text { Hoechst Trespaphan } \\
\text { (Germany) }\end{array}$ & Biophan Poly- $\alpha$-Hydroxypropionates for Film Materials \\
\hline 16 & Kanebo (Japan) & Bellfree, Lacton poly- $\alpha$-hydroxypropionates for granules, threads, film materials \\
\hline 17 & Mitsubishi Plastics (Japan) & Ecoloju Poly- $\alpha$-Hydroxypropionates for Film Materials \\
\hline 18 & Mitsui Chemicals (Japan) & Lacea poly- $\alpha$-hydroxypropionates for granules, film materials \\
\hline 19 & $\begin{array}{l}\text { Mitsui Toatsu Chem. Ltd } \\
\text { (Japan) }\end{array}$ & Products based on starch and polylactide \\
\hline 20 & \begin{tabular}{|l} 
Monsanto Co. (Italy) / ICI. \\
Zeneto Ltd (Great Britain)
\end{tabular} & Copolymer polyhydroxybutyrate-valerate for the production of bottles, toothbrushes \\
\hline 21 & Nature Works (USA) & $\begin{array}{l}\text { Ingeo }{ }^{\mathrm{TM}} \text { polymers for products from coffee capsules and electronics to diapers and napkins. } \\
\text { Vercet }^{\mathrm{TM}} \text { lactides for CASE products (coatings, adhesives, sealants and elastomers), } \\
\text { toners and surfactants }^{\text {and }}\end{array}$ \\
\hline 22 & $\begin{array}{l}\text { NESTLE OY Chem. / Pri- } \\
\text { malco (Finland) }\end{array}$ & Polylactides and starchy plastics \\
\hline 23 & Novamont (Italy) & Produces "Mater Bi" for injection molding, obtaining films from starch \\
\hline 24 & $\begin{array}{l}\text { Planet Polymer / Nippon } \\
\text { Mitsubishi (Japan) }\end{array}$ & $\begin{array}{l}20 \text { types of Enviro Plastics water soluble, compostable, photodegradable injection molding } \\
\text { resins, Aquarbo - polyvinyl alcohol for medical blown films, waste vessels }\end{array}$ \\
\hline 25 & Procter \& Gamble (France) & Nodax polyhydroxyalkanoates for nonwovens, films and fibrous materials \\
\hline 26 & Roquette (France) & More than 650 by-products from corn, wheat, potato and pea starch \\
\hline 27 & Rohm and Haas Co. (USA) & Polyaspartates, water-soluble dispersants, biodegradable dispersants for washing powders \\
\hline 28 & \begin{tabular}{|l|}
$\begin{array}{l}\text { Shell Chem. Co. } \\
\text { (Great Britain) }\end{array}$ \\
\end{tabular} & Several biodegradable polyesters \\
\hline 29 & Shimodzu Co. (Japan) & Transparent, colorless improved Lacty polylactides for injection molding \\
\hline 30 & Silbo (Poland) & Cellulose packaging, new bio-compostable packaging standards \\
\hline 31 & Showa Denko (Japan) & $\begin{array}{l}\text { Bionolle special aliphatic polyesters, polybutylene / succinate and polybutylene / succinate / } \\
\text { adipate copolymers }\end{array}$ \\
\hline 32 & Solvay S. A. (Belgium) & Polylactides for a wide variety of applications \\
\hline 33 & Sukano (Switzerland) & Masterbatches of additives and colorants for biodegradable polymers PLA and PBS \\
\hline 34 & Sunkyong Ltd. (Korea) & Aliphatic polyesters Sky Green \\
\hline 35 & $\begin{array}{l}\text { Total Corbion PLA } \\
\text { (Netherlands) }\end{array}$ & $\begin{array}{l}\text { Luminy }{ }^{\circledR} \text { PLA polylactic acid (PLA) and lactide monomers are high temperature and standard } \\
\text { grades for a wide range from packaging to consumer products, fibers and automobiles }\end{array}$ \\
\hline 36 & Union Carbide Corp. (USA) & $\begin{array}{l}\text { Major supplier of high molecular weight polylactides for the production of films and sacks for } \\
\text { food waste, also high molecular weight, water-soluble and biodegradable polyester Polyox }\end{array}$ \\
\hline
\end{tabular}




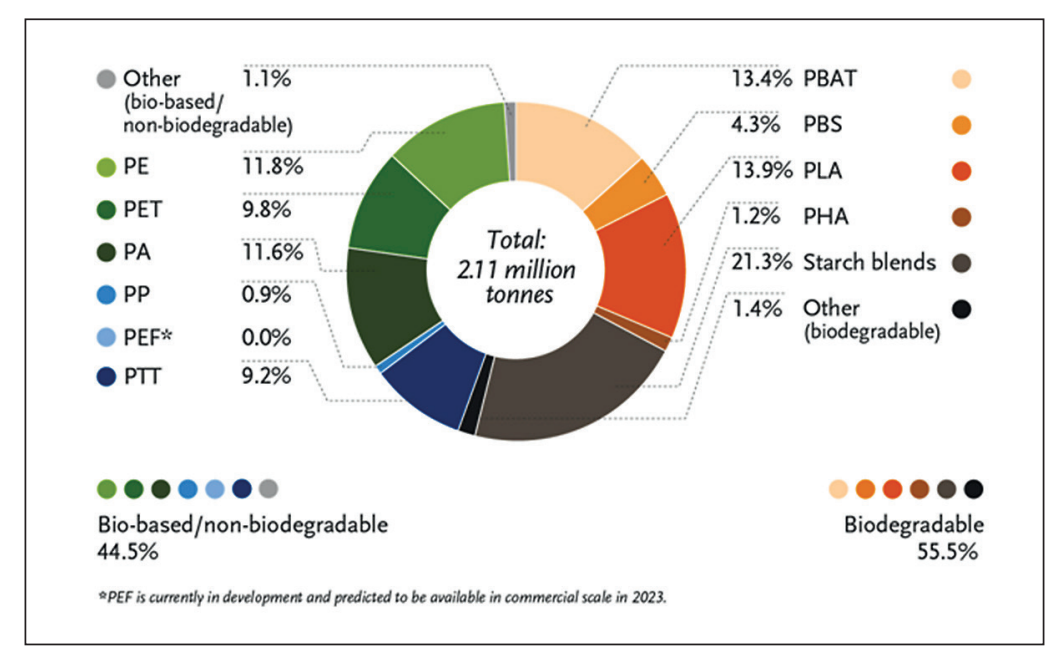

Fig. 3. Production capacity of bioplastics by type in 2019, thousand tons Source: European Bioplastics Institute

Currently, non-biodegradable bio-based plastics account for up to $44.5 \%$ of the total bioplastics produced (Fig. 3) [23].

In 2019, bio-based innovative polypropylene entered the market on a commercial scale. PHA (polyhydroxyalkanoates) is the most developing class of polymers, completely obtained from biomaterial and biodegradable, has a wide range of physical and mechanical properties depending on their chemical composition. PEF* (polyethylene furanoate) is a new polymer, which is expected to enter the market in 2023 [23].

Asian countries are leading as a major hub of the entire bioplastics industry. In 2019, 45\% of the total bioplastics were produced there (Fig. 4) [23].

Initially, biodegradable PM was a mixture of conventional polymers with starch. Now a whole spectrum of new biodegradable plastics has appeared, differing in production technologies and composition (Table 1).
Among domestic manufacturers of biodegradable polymer products, the following can be distinguished [24]:

1) LLC "Company EuroBalt", which launched the production of oxo-biodegradable packaging in 2008;

2) JSC "TIKO-Plastik", producing biodegradable bags with a catalyst additive;

3) DAR PF, certified in October 2009 for production of biodegradable packages;

4) LLC "Artplast", which began production of biodegradable packaging in June 2010;

5) LLC "Biaxplen", which launched in 2008 a line capable of producing biodegradable packaging from bioraw materials (potatoes, corn, etc. - bio-materials with a high starch content);

6) CJSC National Packaging Company "PAGODA", which has biodegradable bags in its range;

7) RT-Khimkompozit has developed the production of biodegradable plastics based on lactic acid. The essence

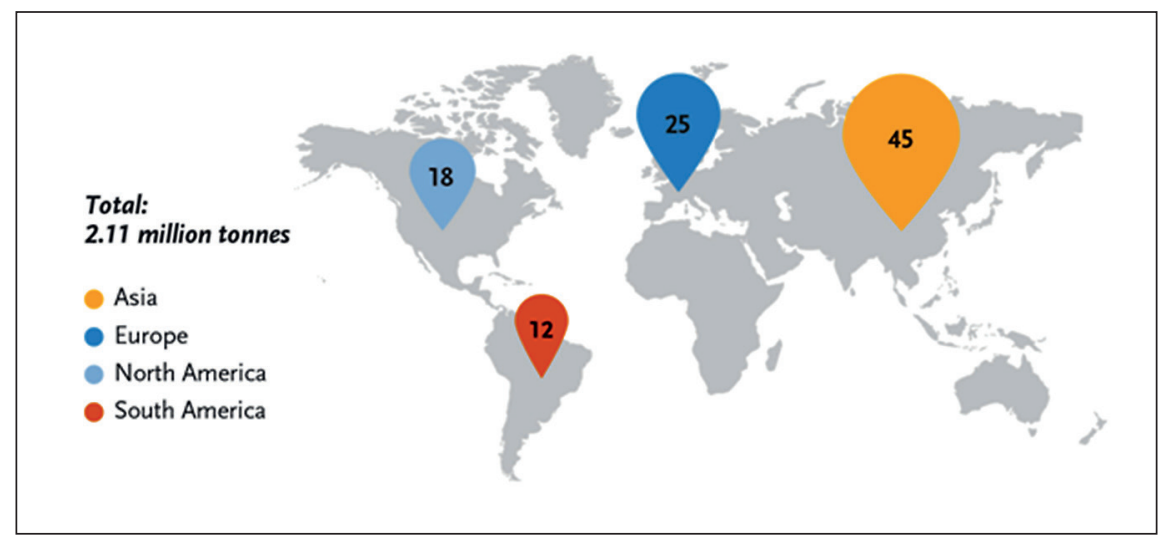

Fig. 4. Production capacity of bioplastics by region in $2019, \%$

Source: European Bioplastics Institute 
of this process is the synthesis of monomers by bacteria from available sugars, the decomposition period during composting is from 20 to 90 days.

Thus, the need for compostable bioplastics is growing, as evidenced by the increase in the number of manufacturers of such materials and products based on them. Natural polymers have high biodegradability, biocompatibility and safety. On the other hand, the use of synthetic materials is due to the fact that they can be adapted to obtain the necessary characteristics by using various manufacturing technologies to reproduce the molecular structure and change mechanical properties depending on needs.

The task of the latest developments in the field of compostable bioplastics is to establish general patterns in the selection of components and technological parameters for the production of materials that combine a high level of operational characteristics with biodegradability, and basic rules for regulating the speed of their safe degradation at the end of service life.

\section{REFERENCES}

1. Geyer R., Jambeck J.R., Law K.L. Production, use, and fate of all plastics ever made. Science Advances. 2017; 3(7): e1700782. Available from: doi: 10.1126/sciadv.1700782.

2. Volkova A.V. Waste disposal market. National Research University Higher School of Economics; 2018.

3. Shishonok M. Modern polymeric materials. Higher School. 2017, 278 p.

4. Potapova E.V. Problem of utilization of plastic waste. Bulletin of the Baikal State University. 2018; 28(4): $535-544$. Available from: doi: 10.17150/2500-2759.

5. Van Sebille E. et al. The physical oceanography of the transport of floating marine debris. Environ. Res. Lett. 2020; 15(2): 023003.

6. Pipia L.K., Elkin A.G. Plastics recycling: market assessment and perspectives. Science abroad. 2018; 1-33.

7. Potapova E.V. The problem of recycling plastic waste. Bulletin of the Baikal State University. 2018; 28(4): 535-544. Available from: doi: 10.17150/2500-2759.

8. Rzayev K.V. Recycling of plastic waste in Russia. Solid household waste. 2017; 1: 7-9.

9. Buzova O.V., Novikova V.O. Recycling of plastic waste. Agency for International Research. 2017; $134-136$.

10. Petrov A.V., Doriomedov M.S., Skripachev S.Yu. Utilization technologies for polymer composite materials (review). Proceedings of VIAM. 2015; 8: 62-73. Available from: doi: 10.15593/24111678/2017.04.08.

11. Niaounakis M. Recycling of flexible plastic packaging. Elsevier; 2020.

12. Madalina E.G. Methods of Recycling, Properties and Applications of Recycled Thermoplastic Polymers. Recycling. 2017; 2(24): 1-11.

13. Mehdi Sadat-Shojai, Gholam-Reza Bakhshandeh. Recycling of PVC wastes. Polymer Degradation and Stability. 2011; 404-415. Available from: doi: 10.1016/j.polymdegradstab.2010.12.001.

14. Hazrat M.A., Rasul M.G, Khan M.M. K. A study of Thermo-Catalytic Degradation for Production of Clean Transport Fuel and Recycling Plastic Wastes. Procedia Engineering. 2015; 105: 865-876. Available from: doi: 10.1016/j. proeng.2015.05.108.

15. Ragart K., Delva L., Kevin V. G. Mechanical and chemical recycling of solid plastic waste. Waste Management. 2017; 69: 24-58. Available from: doi: 10.1016/j.wasman.2017.07.044.

16. Palyga R.B. Potential possibilities of polymer recycling. Solid household waste. 2017;1 (127): 26-29.

17. Prokopchuk N.R., Manulenko A.F., Evsey A.V. Some features of recycling and regulation of the properties of secondary polyvinyl chloride. Proceedings of BSTU. No. 4. Chemistry, technology of organic matter and biotechnology. 2010; 4: 112-114.

18. Davydova V.N., Lukasik V.A., Solovyov Yu.V. Recycling of thermoplastics and thermosets. Volgograd: VolgGTU; 2014.

19. Rio Declaration on environment and development. June 14, 1992. Available from: http://www.wno.org/riodeclaration-on-environment-and-development.

20. Tappel L.J., Nomura R.C., Christopher T. Mini-Review: Biosynthesis of Poly (hydroxyalkanoates). Polymer Reviews. 2009; 49(3): 226-248. Available from: doi: 10.1080/15583720903048243.

21. Kim Y.B., Lenz R.W. Polyesters from microorganisms. Advances in Biochemical Engineering. Biotechnology. 2001; 71: 51-79. Available from: doi: 10.1007/3-540-40021-4_2.

22. Hong Chua. Accumulation of biopolymers in activated sludge biomass. Applied Biochemistry and Biotechnology. 1999; 78(1-3): 389-399. Available from: doi: 10.1385/ABAB:78:1-3:389. 
23. Market data on bioplastics. European bioplastics. Available from: https://www.european-bioplastics.org/market/ (03.02.2015).

24. Parmukhina E.L. Russian market of biodegradable packaging. Ecological Bulletin of Russia; Research company RESEARCH.TECHART. 2011; 2: 32-33.

The paper «Biodegradable polymer materials and modifying additives: state of the art. Part Il» will be published in the journal «Nanotechnologies in Construction» N 1/2021

\section{INFORMATION ABOUT THE AUTHORS}

Irina N. Vikhareva, Assistant, Applied and Natural Sciences Department, Ufa State Petroleum Technological University, Ufa, Russia, ORCID: https://orcid.org/0000-0002-5681-2767, e-mail: irina.vikhareva2009@yandex.ru

IInar I. Zaripov, Undergraduate, Applied and Natural Sciences Department, Ufa State Petroleum Technological University, Ufa, Russia, ORCID: https://orcid.org/0000-0003-2594-3753, e-mail: ilnar.zaripov1998@mail.ru

Diana F. Kinzyabulatova, Student, Ufa State Petroleum Technological University, Ufa, Russia, ORCID: https://orcid.org/0000-0002-4442-9269, e-mail: dinkin567890@yandex.ru

Nail S. Minigazimov, Dr. Sci. (Eng.), Prof., Department of Environmental Protection and Natural Resources Management, Ufa State Petroleum Technological University, Ufa, Russia, e-mail: oosripr@rusoil.net

Guliya K. Aminova, Dr. Sci. (Eng.), Prof., Applied and Natural Sciences Department, Ufa State Petroleum Technological University, Ufa, Russia, e-mail: aminovagk@inbox.ru

\section{Authors declare the absence of any competing interests.}

Received: 15.10 .2020$.

Revised: 26.11.2020.

Accepted: 29.11.2020. 